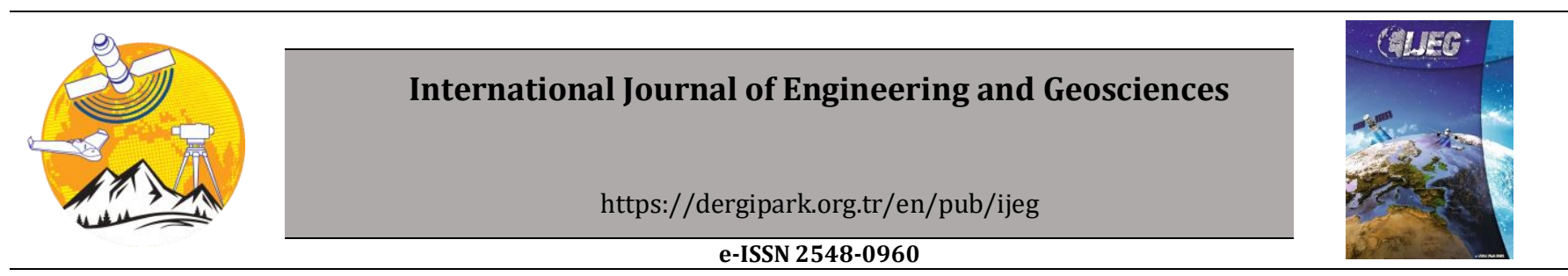

\title{
Estimating the seasonal relationship between land surface temperature and normalized difference bareness index using Landsat data series
}

\author{
Subhanil Guha*1 (D) , Himanshu Govil1 ${ }^{1}$ \\ ${ }^{1}$ National Institute of Technology Raipur, Department of Applied Geology, Raipur, India
}

Keywords
Landsat
LST
LULC
NDBaI
Raipur

\begin{abstract}
The present study analyzes the seasonal variability of the relationship between the land surface temperature (LST) and normalized difference bareness index (NDBaI) on different land use/land cover (LULC) in Raipur City, India by using sixty-five Landsat images of four seasons (pre-monsoon, monsoon, post-monsoon, and winter) of 1991-1992, 1995-1996, 1999-2000, 2004-2005, 2009-2010, 2014-2015, and 2018-2019. The mono-window algorithm was used to retrieve LST and Pearson's correlation coefficient was used to generate the LST-NDBaI relationship. The post-monsoon season builds the best correlation (0.59) among the four seasons. The water bodies builds a moderate to strong positive correlation $(>0.50)$ in all the four seasons. On green vegetation, this correlation is moderate to strong positive $(>0.54)$ in the three seasons, except the pre-monsoon season. The built-up area and bare land generate a moderate positive correlation $(>0.34$ ) in all the four seasons. Among the four seasons, the postmonsoon season builds the best correlation for all LULC types, whereas the pre-monsoon season has the least correlation. This research work is useful for environmental planning of other citieswith similar climatic conditions.
\end{abstract}

\section{INTRODUCTION}

Land surface temperature (LST) is an indispensable parameter in analyzing the bio-geochemical functions of the earth surface features (Tomlinson et al. 2011; Hao et al. 2016; Guha et al. 2020a). Green plants, wetlands, and water bodies generate low LST, whereas human settlement, and bare land surface produce high LST in the summer season of tropical areas (Chen et al. 2006). Thus, LST and normalized difference spectral indices related studies are quite important in the ecological planning of the recent urban agglomerations (Sekertekin et al. 2016; Li et al. 2016; Guha et al. 2020b). Normalized difference bareness index (NDBaI) is one of the most popular indices for bare land extraction that is often used in LULC and LST related studies (Zhao and Chen 2005; Chen et al. 2006; Essa et al. 2012; Guha et al. 2017).

Several research articles presented the LST-NDBaI relationship in recent years. As-Syakur et al. (2012) investigates various bareness indices for bare land mapping in Denpasar of Bali, Indonesia. Ahmed et al. (2013) used NDBaI along with other LULC indices to simulate the land surface changes and their impact on
LST in Dhaka, Bangladesh. Sharma et al. (2013) examined the relationship between LST and NDBaI in Surat City of India. Guo et al. (2014) estimated sub-pixel LST and built a relationship between LST and NDBaI in Guangzhou core urban area of China. Ali et al. (2017) compared the relationship of LST with NDBaI and other LULC indices in London and Baghdad cities. Macarof et al. (2017) investigated the relationship between LST and NDBaI in Iaşi Municipality Area of eastern Romania from 2013 to 2016 by using Landsat 8 data. Alibakshi et al. (2020) investigated the relationship between NDBaI and LST from 2001 to 2015 in Tehran and its satellite cities in Iran by the geographically weighted regression model using Landsat 7 data. Alexander (2020) evaluated the LST-NDBaI relationship in Aarhus City of Denmark by using Landsat 8 data. Jain et al. (2020) investigated the LST-NDBaI relationship in Nagpur City, India from 2000 to 2015 by using Landsat data.

The LST and NDBaI values vary due to the seasonal variation of various atmospheric components. Thus, to estimate the characteristics of seasonal variation of the LST-NDBaI relationship in Indian context, Raipur City ofChhattisgarh has been chosen. The main aim of the study is to estimate the seasonal variation of LST-NDBaI 
relationship on different categories of LULC. The study will be a beneficial one for ecological planning and management in an urban environment.

\section{STUDY AREA AND DATA}

Figure 1 shows the geographical location of Raipur city of India which extends from 21011'22"N to $21^{\circ} 20^{\prime} 02^{\prime \prime} \mathrm{N}$ and from $81^{\circ} 32^{\prime} 20^{\prime \prime} \mathrm{E}$ to $81^{\circ} 41^{\prime} 50^{\prime \prime E}$. The city covers an area of around $165 \mathrm{~km}^{2}$. Figure 1(a) presents the outline map of India (URL-1). Figure 1(b) presents the outline map of Chhattisgarh State (URL-1). Figure 1(c) represents the false colour composite (FCC) image of Raipur City (URL-2) from recent Landsat 8 data of 07 November 2018(URL-3). Figure 1(d) shows the digital elevation map (DEM) of Raipur City produced by the ArcGIS software using the last available ASTER DEM data of 11 October 2011 (URL-3). The city is characterised by the tropical dry and wet type of climate (URL-4). The mean monthly temperature ranges from $12^{\circ} \mathrm{C}$ to $42^{\circ} \mathrm{C}$. May presents the highest average temperature $\left(35^{\circ} \mathrm{C}\right)$, while December presents the lowest average temperature $\left(20^{\circ} \mathrm{C}\right)$. The highest average rainfall (327 mm) is observed in July. March, April, and May are considered as the summer or pre-monsoon months. June, July, August, and September are the monsoon months. The post-monsoon months are October and November, when the weather remains pleasant. The winter months are December, January, and February, when the temperature falls significantly.
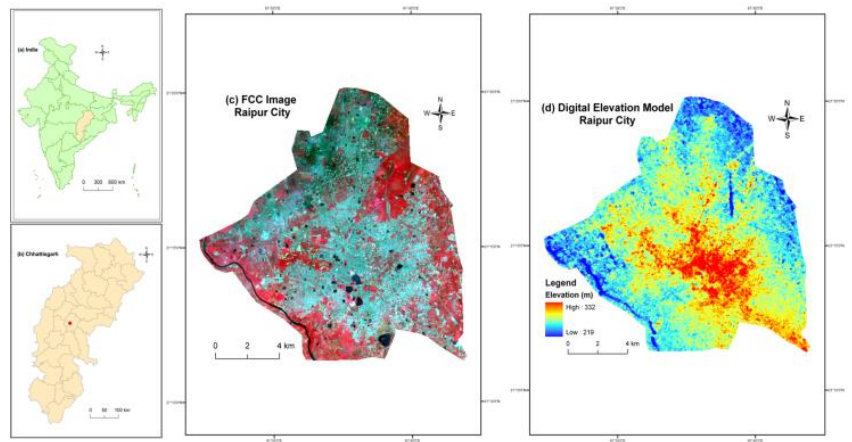

Figure 1. Location of the study area: (a) India highlighting Chhattisgarh; (b) Chhattisgarh highlighting Raipur City; (c) False colour composite image of Raipur; (d) Digital elevation model of Raipur.

Table 1 shows the specification of Landsat data of different sensors. The band 10 of Landsat 8 thermal infrared sensors (TIRS) dataset was used as the only TIR band in the present study due to a larger calibration certainty (Barsi et al. 2014). Landsat 5 thematic mapper (TM) data has only one TIR band (band 6) of $120 \mathrm{~m}$ resolution. Landsat 7 enhanced thematic mapper plus (ETM+) data has a TIR band (band 6) of $60 \mathrm{~m}$ resolution. The TIR bands of all the Landsat sensors were resampled to $30 \mathrm{~m}$ pixel size by the data provider (USGS) as the spatial resolution of visible to nearinfrared (VNIR) and shortwave infrared (SWIR) bands of the three types of Landsat sensors is $30 \mathrm{~m}$. All theraster calculations were processed in the environment of ArcGIS 9.3 and ERDAS IMAGINE 9.1 software.
Table 1. Specification of the used Landsat data

\begin{tabular}{|c|c|c|c|}
\hline $\begin{array}{l}\text { Date of } \\
\text { acquisition }\end{array}$ & $\begin{array}{l}\text { Time } \\
\text { (UTC) }\end{array}$ & $\begin{array}{r}\text { Cloud } \\
\text { cover } \\
(\%) \\
\end{array}$ & $\begin{array}{r}\text { Resolution } \\
\text { of TIR } \\
\text { bands (m) }\end{array}$ \\
\hline 18-Mar-91 & $04: 17: 34$ & 0 & 120 \\
\hline 03-Apr-91 & 04:17:46 & 0 & 120 \\
\hline 21-May-91 & 04:18:39 & 1 & 120 \\
\hline 26-Sep-91 & $04: 20: 03$ & 13 & 120 \\
\hline 12-0ct-91 & $04: 20: 12$ & 6 & 120 \\
\hline 13-Nov-91 & 04:20:19 & 1 & 120 \\
\hline 16-Jan-92 & $04: 20: 22$ & 3 & 120 \\
\hline 01-Feb-92 & $04: 20: 27$ & 0 & 120 \\
\hline 17-Feb-92 & $04: 20: 15$ & 4 & 120 \\
\hline 14-Apr-95 & 04:05:06 & 0 & 120 \\
\hline 10-Dec-95 & 03:56:47 & 0 & 120 \\
\hline 27-Jan-96 & 04:00:14 & 0 & 120 \\
\hline 23-Sep-96 & $04: 14: 16$ & 2 & 120 \\
\hline 09-0ct-96 & 04:15:07 & 0 & 120 \\
\hline $25-0 c t-96$ & $04: 15: 55$ & 5 & 120 \\
\hline 10-Nov-96 & 04:16:41 & 7 & 120 \\
\hline 11-Nov-99 & 04:49:00 & 0 & 60 \\
\hline 30-Jan-00 & 04:48:55 & 0 & 60 \\
\hline 03-Apr-00 & $04: 48: 35$ & 0 & 60 \\
\hline 05-May-00 & $04: 48: 20$ & 0 & 60 \\
\hline 26-Sep-00 & $04: 46: 33$ & 6 & 60 \\
\hline 15-Dec-00 & 04:46:31 & 0 & 60 \\
\hline 21-Mar-04 & $04: 35: 14$ & 0 & 120 \\
\hline 22-Apr-04 & 04:36:01 & 1 & 120 \\
\hline 24-May-04 & $04: 36: 54$ & 0 & 120 \\
\hline 09-Jun-04 & $04: 37: 23$ & 9 & 120 \\
\hline 29-Sep-04 & $04: 40: 16$ & 9 & 120 \\
\hline 15-Oct-04 & $04: 40: 36$ & 4 & 120 \\
\hline 16-Nov-04 & 04:41:11 & 0 & 120 \\
\hline 02-Dec-04 & 04:41:33 & 0 & 120 \\
\hline 18-Dec-04 & $04: 41: 52$ & 0 & 120 \\
\hline 19-Jan-05 & $04: 42: 17$ & 0 & 120 \\
\hline 04-Feb-05 & $04: 42: 29$ & 0 & 120 \\
\hline 03-Mar-09 & $04: 42: 22$ & 0 & 120 \\
\hline 19-Mar-09 & $04: 42: 44$ & 2 & 120 \\
\hline 04-Apr-09 & 04:43:05 & 0 & 120 \\
\hline 20-Apr-09 & $04: 43: 24$ & 0 & 120 \\
\hline 06-May-09 & 04:43:42 & 0 & 120 \\
\hline 22-Мау-09 & 04:44:00 & 1 & 120 \\
\hline 23-Jun-09 & $04: 44: 35$ & 0 & 120 \\
\hline 13-Oct-09 & $04: 46: 12$ & 0 & 120 \\
\hline 29-0ct-09 & $04: 46: 20$ & 0 & 120 \\
\hline 16-Dec-09 & $04: 46: 44$ & 1 & 120 \\
\hline 17-Jan-10 & $04: 46: 55$ & 6 & 120 \\
\hline 02-Feb-10 & $04: 46: 59$ & 0 & 120 \\
\hline 18-Feb-10 & $04: 47: 02$ & 7 & 100 \\
\hline 17-Mar-14 & $04: 56: 36$ & 0 & 100 \\
\hline 02-Apr-14 & 04:56:19 & 0 & 100 \\
\hline 20-May-14 & 04:55:38 & 5 & 100 \\
\hline 05-Jun-14 & $04: 55: 45$ & 0 & 100 \\
\hline 12-Nov-14 & $04: 56: 21$ & 7 & 100 \\
\hline 30-Dec-14 & 04:56:09 & 0 & 100 \\
\hline 15-Jan-15 & 04:56:09 & 0 & 100 \\
\hline 31-Jan-15 & $04: 56: 04$ & 0 & 100 \\
\hline 16-Feb-15 & $04: 55: 55$ & 0 & 100 \\
\hline 12-Mar-18 & $04: 55: 43$ & 2 & 100 \\
\hline 28-Mar-18 & $04: 55: 36$ & 0 & 100 \\
\hline 15-Мay-18 & 04:55:08 & 0 & 100 \\
\hline 16-Jun-18 & 04:55:01 & 2 & 100 \\
\hline 06-0ct-18 & $04: 55: 53$ & 0 & 100 \\
\hline 22-0ct-18 & 04:55:59 & 0 & 100 \\
\hline 07-Nov-18 & 04:56:03 & 0 & 100 \\
\hline 25-Dec-18 & $04: 55: 59$ & 0 & 100 \\
\hline 11-Feb-19 & $04: 55: 52$ & 0 & 100 \\
\hline 27-Feb-19 & $04: 55: 48$ & 4 & 100 \\
\hline
\end{tabular}

\section{METHODOLOGY}

\subsection{Retrieving LST from Landsat Data}

In this study, the mono-window algorithm was applied to retrieve LST from multi-temporal Landsat satellite sensors (Qin et al. 2001) where three necessary 
parameters are ground emissivity, atmospheric transmittance, and effective mean atmospheric temperature. At first, the original TIR bands $(100 \mathrm{~m}$ resolution for Landsat 8 OLI/TIRS data, $120 \mathrm{~m}$ resolution for Landsat $5 \mathrm{TM}$ data, and $60 \mathrm{~m}$ resolution for Landsat 7 ETM+ data) were resampled into $30 \mathrm{~m}$ by USGS data centre for further application.

The TIR pixel values are firstly converted into radiance from digital number (DN) values (Markham \& Barkar 1985). Radiance for TIR band of Landsat 5 TM data and Landsat 7 ETM+ data is obtained using Eq. (1) (URL-3):

$$
L_{\lambda}=\left[\frac{L_{M A X \lambda}-L_{M I N \lambda}}{Q C A L_{M A X}-Q C A L_{M I N}}\right] *\left[Q_{C A L}-Q C A L_{M I N}\right]+L_{M I N \lambda}
$$

where, $L_{\lambda}=$ Top of Atmosphere (TOA) spectral radiance $\left(\mathrm{Wm}^{-2} \mathrm{Sr}^{-1} \mathrm{~mm}^{-1}\right), Q_{C A L}=$ quantized calibrated pixel value in $\mathrm{DN}, L_{M I N \lambda}\left(\mathrm{Wm}^{-2} \mathrm{sr}^{-1} \mathrm{~mm}^{-1}\right)=$ spectral radiance scaled to $Q C A L_{M I N}, L_{M A X \lambda}\left(\mathrm{Wm}^{-2} \mathrm{sr}^{-1} \mathrm{~mm}^{-1}\right)=$ spectral radiance scaled to $Q C A L_{M A X}, Q C A L_{M I N}=$ minimum quantized calibrated pixel value in DN and $Q C A L_{M A X}=$ maximum quantized calibrated pixel value in DN. $L_{M I N \lambda}, L_{M A X \lambda}, Q C A L_{M I N}$, and $Q C A L_{M A X}$ values are obtained from the metadata file of Landsat TM and ETM+ data. Radiance for Landsat 8 TIR band is obtained from Eq. (2) (Zanter 2019):

$$
L_{\lambda}=M_{L} \cdot Q_{C A L}+A_{L}
$$

where, $L_{\lambda}=$ TOA spectral radiance $\left(\mathrm{Wm}^{-2} \mathrm{sr}^{-1} \mathrm{~mm}^{-1}\right)$, $M_{L}=$ band-specific multiplicative rescaling factor from the metadata, $A_{L}=$ band-specific additive rescaling factor from the metadata, $Q_{C A L}=$ quantized and calibrated standard product pixel values (DN). All of these variables can be retrieved from the metadata file of Landsat 8 data.

For Landsat 5 and 7 data, the reflectance value is obtained from radiances using Eq. (3) (URL-3):

$$
\rho_{\lambda}=\frac{\pi \cdot L_{\lambda} \cdot d^{2}}{E S U N_{\lambda} \cdot \cos \theta_{s}}
$$

where, $\rho_{\lambda}=$ unitless planetary reflectance, $L_{\lambda}=$ TOA spectral radiance $\left(\mathrm{Wm}^{-2} \mathrm{sr}^{-1} \mu \mathrm{m}^{-1}\right), d=$ Earth-Sun distance in astronomical units, $E S U N_{\lambda}=$ mean solar exo-atmospheric spectral irradiances $\left(\mathrm{Wm}^{-2} \mu \mathrm{m}^{-1}\right)$ and $\theta_{s}=$ solar zenith angle in degrees. $E S U N_{\lambda}$ values for each band of Landsat 5 and 7 can be obtained from the handbooks of the related mission. $\theta_{s}$ and $d$ values can be attained from the metadata file (Coll et al. 2010).

For Landsat 8 data, reflectance conversion can be applied to DN values directly as in Eq. (4) (Zanter 2019):

$$
\rho_{\lambda}=\frac{M_{\rho} \cdot Q_{C A L}+A_{\rho}}{\sin \theta_{S E}}
$$

where, $M_{\rho}=$ band-specific multiplicative rescaling factor from the metadata, $A_{\rho}=$ band-specific additive rescaling factor from the metadata, $Q_{C A L}=$ quantized and calibrated standard product pixel values (DN) and $\theta_{S E}=$ local sun elevation angle from metadata file.

Eq. (5) is used to convert the spectral radiance to atsensor brightness temperature (Wukelic et al. 1989; Chen et al. 2006):

$$
T_{b}=\frac{K_{2}}{\ln \left(\frac{K_{1}}{L_{\lambda}}+1\right)}
$$

where, $T_{b}=$ brightness temperature in Kelvin $(\mathrm{K})$, $L_{\lambda}=$ spectral radiance in $\mathrm{Wm}^{-2} \mathrm{sr}^{-1} \mathrm{~mm}^{-1} ; K_{2}$ and $K_{1}$ =calibration constants. For Landsat 8 data, $K_{1}=774.89$, $K_{2}=1321.08\left(\mathrm{Wm}^{-2} \mathrm{sr}^{-1} \mathrm{~mm}^{-1}\right)$. For Landsat 7 data, $K_{1}=$ 666.09, $K_{2}=1282.71\left(\mathrm{Wm}^{-2} \mathrm{sr}^{-1} \mathrm{~mm}^{-1}\right)$. For Landsat 5 data, $K_{1}=607.76, K_{2}=1260.56\left(\mathrm{Wm}^{-2} \mathrm{sr}^{-1} \mathrm{~mm}^{-1}\right)$.

The land surface emissivity $\varepsilon$, is measured from Eq. (6) using the NDVI Thresholds Method (Sobrino et al. 2001, 2004; Vlassova et al. 2014).

$$
\varepsilon=\varepsilon_{v} F_{v}+\varepsilon_{s}\left(1-F_{v}\right)+d \varepsilon
$$

where, $\varepsilon=$ land surface emissivity, $\varepsilon_{v}=$ vegetation emissivity, $\varepsilon_{s}=$ soil emissivity, $F_{v}=$ fractional vegetation, $d \varepsilon=$ effect of the geometrical distribution of the natural surfaces and internal reflections that can be expressed by Eq. (7):

$$
d \varepsilon=\left(1-\varepsilon_{s}\right)\left(1-F_{v}\right) F \varepsilon_{v}
$$

where, $\quad \varepsilon_{v}=$ vegetation emissivity, $\varepsilon_{s}=$ soil emissivity, $F_{v}=$ fractional vegetation, $F=$ a shape factor whose mean is 0.55 , the value of $d \varepsilon$ may be $2 \%$ for mixed land surfaces (Sobrino et al. 2004).

The fractional vegetation $F_{v}$, of each pixel, is estimated from the NDVI using Eq. (8) (Carlson \& Ripley 1997):

$$
F_{v}=\left(\frac{N D V I-N D V \mathrm{I}_{\min }}{N D V \mathrm{I}_{\max }-N D V \mathrm{I}_{\min }}\right)^{2}
$$

where, $\quad(a) N D V \mathrm{I}<0.2$ for bare soil; (b) NDV I $>0.5$ for vegetation; (c) $0.2<=N D V \mathrm{I}<=0.5$ for mixed land with bare soil 
and vegetation; $(d) N D V I<0$ for water body (Sobrino et al. 2001, 2004; Vlassova et al. 2014).

Finally, the land surface emissivity $\varepsilon$ can be expressed by Eq. (9):

$$
\varepsilon=0.004 * F_{v}+0.986
$$

where, $\varepsilon=$ land surface emissivity, $F_{v}=$ fractional vegetation.

Water vapour content is calculated by Eq. (10) (Yang and Qie 1996; Li 2006):

$w=0.0981 *\left[10 * 0.6108 * \exp \left(\frac{17.27 *\left(T_{0}-273.15\right)}{237.3+\left(T_{0}-273.15\right)}\right) * R H\right]+0.1697$

where, $w=$ water vapour content $\left(\mathrm{g} / \mathrm{cm}^{2}\right), T_{0}=$ near-surface air temperature in Kelvin $(\mathrm{K}), \quad R H=$ relative humidity (\%). These parameters of atmospheric profile are obtained from the Meteorological Centre, Raipur (http://www.imdraipur.gov.in). Atmospheric transmittance is estimated for Raipur City using Eq. (11) (Qin et al. 2001; Sun et al. 2010):

$$
\tau=1.031412-0.11536 w
$$

where, $\tau$ =total atmospheric transmittance, $w=$ water vapour content $\left(\mathrm{g} / \mathrm{cm}^{2}\right)$.

Raipur City is located in the tropical region. Thus, Eq. (12) is applied to calculate the effective mean atmospheric transmittance of Raipur (Qin et al. 2001; Sun et al. 2010):

$$
T_{a}=17.9769+0.91715 T_{0}
$$

LST is retrieved from Landsat 5, Landsat 7, and Landsat 8 satellite data by using Eq. (13-15) (Qin et al. 2001):

$$
\begin{aligned}
& T_{s}=\frac{\left[a(1-C-D)+(b(1-C-D)+C+D) T_{b}-D T_{a}\right]}{C} \\
& C=\varepsilon \tau \\
& D=(1-\tau)[1+(1-\varepsilon) \tau]
\end{aligned}
$$

where, $\varepsilon=$ land surface emissivity, $\tau$ =total atmospheric transmittance, $C$ and $D=$ internal parameters based on atmospheric transmittance and land surface emissivity, $T_{b}=$ at-sensor brightness temperature, $T_{a}=$ mean atmospheric temperature, $T_{0}=$ near-surface air temperature, $T_{s}=$ land surface temperature, $a=-67.355351, b=0.458606$.

\subsection{Retrieving Extraction of Different Types of LULC by Using NDBaI}

The study emphasized NDBaI for determining the relationship with LST (Zhao and Chen 2005; Chen et al.
2006). NDBaI is determined by the SWIR and TIR bands. For, Landsat 5 and Landsat 7 data, band 5 and band 6 are used as the SWIR and TIR band, respectively. For Landsat 8 data, band 6 and band 10 are used as the SWIR and TIR bands, respectively (Table 2). The value of NDBaI ranges between -1 and +1 . Generally, the positive value of NDBaI indicates the bare land. The bareness increases with the increase of the positive NDBaI. NDBaI value ranges between -0.2 to 0 shows the built-up area, NDBaI > 0 shows the bare land,NDBaI < 0.25 presents the vegetation, and NDBaI < -0.65 presents the water bodies (Chen et al. 2006). LULC maps have been generated using the aforesaid threshold limits of NDBaI and the results have been validated by

\begin{tabular}{|c|c|c|c|}
\hline Acronym & Description & Formulation & References \\
\hline \multirow{2}{*}{ NDBaI } & \multirow{2}{*}{$\begin{array}{l}\text { Normalized } \\
\text { difference } \\
\text { bareness index }\end{array}$} & SWIR1 - TIR & \multirow{2}{*}{$\begin{array}{l}\text { Zhao and Chen } \\
2005 \text {; Chen et al. } \\
2006\end{array}$} \\
\hline & & $\overline{S W I R 1+T I R}$ & \\
\hline
\end{tabular}
the maximum likelihood classification. The average calculated values of the Kappa coefficient and overall accuracy for all the images are 0.91 and 92.19\%, respectively.

Table 2. General description of NDBaI

\subsection{LST-NDBaI relationship generation on different types of LULC}

LST-NDBaI correlation develops on the following LULC categories, i.e., green plants, water bodies, human settlement, and bare lands. The study also evaluates the seasonal and temporal variability of the LST-NDBaI correlation.

\section{RESULTS AND DISCUSSION}

\subsection{Extraction of LULC Types Using NDBaI}

Figure 2 shows the classified LULC maps from the post-monsoon data,prepared by the threshold limits of NDBaI and these maps have been validated by applying the maximum likelihood classification method. In the earlier period, the built-up area and bare land were developedalong the middle portion of the city. The northwest part has been rapidly urbanized till 2004-05. Most of the vegetation covered areasof this area were converted into the built-up areas. However, in the last phase of the study period, most of the remaining vegetal covered partsweredecreased due to quick convertion into bare land and built-up area. This conversion was mainly by the anthropogenic activities, although some natural desertification process was also responsible in the semi-arid parts. Conversion of the water bodies is lesser than the vegetation. On the other hand, a high increasing rate was observed for the settlement and bare earth surface (approximately $3 \mathrm{~km}^{2}$ area annually). 


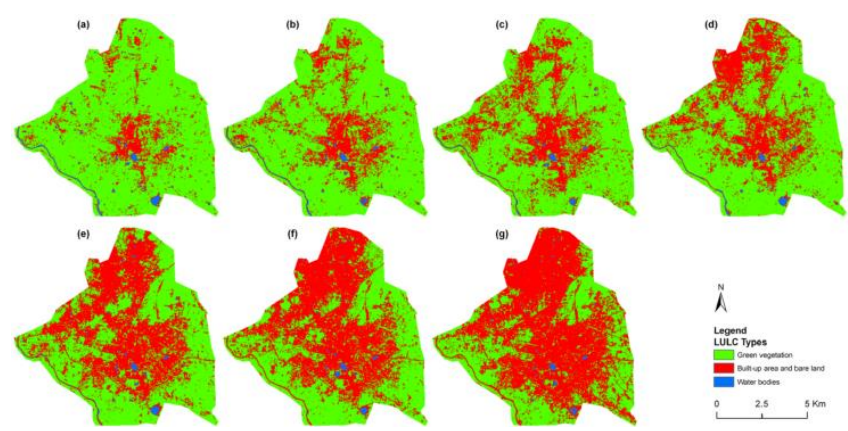

Figure 2. LULC maps of the study area: (a) 1991-1992; (b) 1995-1996; (c) 1999-2000; (d) 2004-2005; (e) 2009-2010; (f) 2014-2015; (g) 2018-2019.

\subsection{Seasonal Distribution of LST and NDBaI}

A prominent seasonal variation in the minimum, maximum, mean and standard deviation values of LST is noticed in Table 3. The average values of LST and the Pearson's correlation coefficient between LST-NDBaI relationship from 1991-92 to 2018-19 have been shown in italic font text inside Table 3.

Table 3. Seasonal variation of LST and LST-NDBaI relationship ( 0.05 level of significance).

\begin{tabular}{|c|c|c|c|c|c|c|}
\hline \multirow[t]{2}{*}{ Season } & \multirow{2}{*}{$\begin{array}{l}\text { Year of } \\
\text { acquisition }\end{array}$} & \multicolumn{4}{|c|}{ LST $\left({ }^{\circ} \mathrm{C}\right)$} & \multirow{2}{*}{$\begin{array}{l}\text { Correlation } \\
\text { coefficients } \\
\text { for LST-NDBal } \\
\text { relationship }\end{array}$} \\
\hline & & Min. & Max. & Mean & Std. & \\
\hline \multirow{8}{*}{ Pre-monsoon } & $\begin{array}{l}1991-92 \\
\end{array}$ & 23.81 & 36.27 & 31.54 & 1.52 & 0.58 \\
\hline & $1995-96$ & 24.54 & 41.07 & 34.64 & 1.89 & 0.51 \\
\hline & $1999-00$ & 26.36 & 42.23 & 36.38 & 1.93 & 0.49 \\
\hline & 2004-05 & 26.95 & 44.07 & 38.01 & 2.19 & 0.48 \\
\hline & 2009-10 & 28.81 & 46.48 & 39.60 & 2.54 & 0.43 \\
\hline & 2014-15 & 31.93 & 48.22 & 41.28 & 1.75 & 0.41 \\
\hline & 2018-19 & 33.46 & 51.11 & 43.74 & 1.75 & 0.40 \\
\hline & Average & 27.98 & 44.21 & 37.88 & 1.94 & 0.47 \\
\hline \multirow{8}{*}{ Monsoon } & 1991-92 & 19.87 & 30.83 & 25.74 & 1.41 & 0.66 \\
\hline & $1995-96$ & 21.21 & 33.01 & 26.50 & 1.33 & 0.54 \\
\hline & 1999-00 & 22.76 & 35.91 & 27.81 & 1.34 & 0.53 \\
\hline & 2004-05 & 24.17 & 36.20 & 31.32 & 1.33 & 0.54 \\
\hline & 2009-10 & 25.94 & 38.38 & 33.06 & 2.40 & 0.56 \\
\hline & 2014-15 & 27.74 & 40.15 & 34.87 & 1.68 & 0.50 \\
\hline & 2018-19 & 30.59 & 41.98 & 37.30 & 1.13 & 0.55 \\
\hline & Average & 24.61 & 36.64 & 30.94 & 1.52 & 0.56 \\
\hline \multirow{8}{*}{ Post-monsoon } & 1991-92 & 19.72 & 29.56 & 24.32 & 1.72 & 0.69 \\
\hline & $1995-96$ & 20.42 & 30.33 & 25.12 & 1.34 & 0.59 \\
\hline & 1999-00 & 22.41 & 33.47 & 26.84 & 1.91 & 0.57 \\
\hline & 2004-05 & 23.03 & 35.25 & 28.01 & 1.71 & 0.56 \\
\hline & 2009-10 & 24.62 & 37.91 & 30.26 & 1.60 & 0.58 \\
\hline & 2014-15 & 26.24 & 38.22 & 31.68 & 1.12 & 0.56 \\
\hline & 2018-19 & 28.92 & 41.28 & 33.70 & 1.34 & 0.57 \\
\hline & Average & 23.62 & 35.15 & 28.56 & 1.53 & 0.59 \\
\hline \multirow[t]{8}{*}{ Winter } & 1991-92 & 18.22 & 28.33 & 23.29 & 1.22 & 0.53 \\
\hline & $1995-96$ & 20.08 & 28.68 & 24.40 & 1.04 & 0.48 \\
\hline & 1999-00 & 20.44 & 32.80 & 25.21 & 1.81 & 0.46 \\
\hline & 2004-05 & 21.08 & 33.21 & 26.47 & 1.25 & 0.44 \\
\hline & 2009-10 & 22.06 & 34.36 & 27.98 & 1.23 & 0.42 \\
\hline & 2014-15 & 22.80 & 36.21 & 28.90 & 1.39 & 0.41 \\
\hline & 2018-19 & 24.31 & 38.36 & 30.46 & 1.37 & 0.37 \\
\hline & Average & 21.28 & 33.14 & 26.67 & 1.33 & 0.44 \\
\hline
\end{tabular}

The mean LST of the city was increased gradually. The pre-monsoon season always createshighmean LST values $\left(31.54^{\circ} \mathrm{C}\right.$ in $1991-92,34.64^{\circ} \mathrm{C}$ in $1995-96,36.38^{\circ} \mathrm{C}$ in $1999-00,38.01^{\circ} \mathrm{C}$ in $2004-05,39.60^{\circ} \mathrm{C}$ in $2009-10$, $41.28^{\circ} \mathrm{C}$ in $2014-15$, and $43.74{ }^{\circ} \mathrm{C}$ in $2018-19$ ) (Figure 3 ). In the urban heat island zones, the LST-NDBaI relationship is direct or high LST areas have high NDBaI values. Moreover, at the micro-level analysis, the high peaks of LST also presented the high peaks of NDBaI. The correlation coefficient values between the LST and NDBaI are positive throughout the span. In the postmonsoon season, the best mean correlation coefficient value $(0.59)$ is found, followed by the monsoon $(0.56)$, pre-monsoon (0.48), and winter (0.44) seasons. Hence, it can be concluded that wet weather produce a better LST-NDBaI relationship.

Figure 3 shows that in the summer season of 201819 , the LST for most of the places $(>90 \%)$ have $>40^{\circ} \mathrm{C}$. In winter, LST of the whole city is less than $40^{\circ} \mathrm{C}$. A moderate LST values are noticed in the monsoon and post-monsoon seasons. The mean LST of the study area has been gradually increased between 1991-92 and 2018-19. The converted bare land and built-up area produce high LST value compared to the other LULC categories. The low LST value is found in the unchanged vegetation covered area. The moderate LST value is observed in the unchanged water bodie, wetland, orsettlement with hometaead orchard.

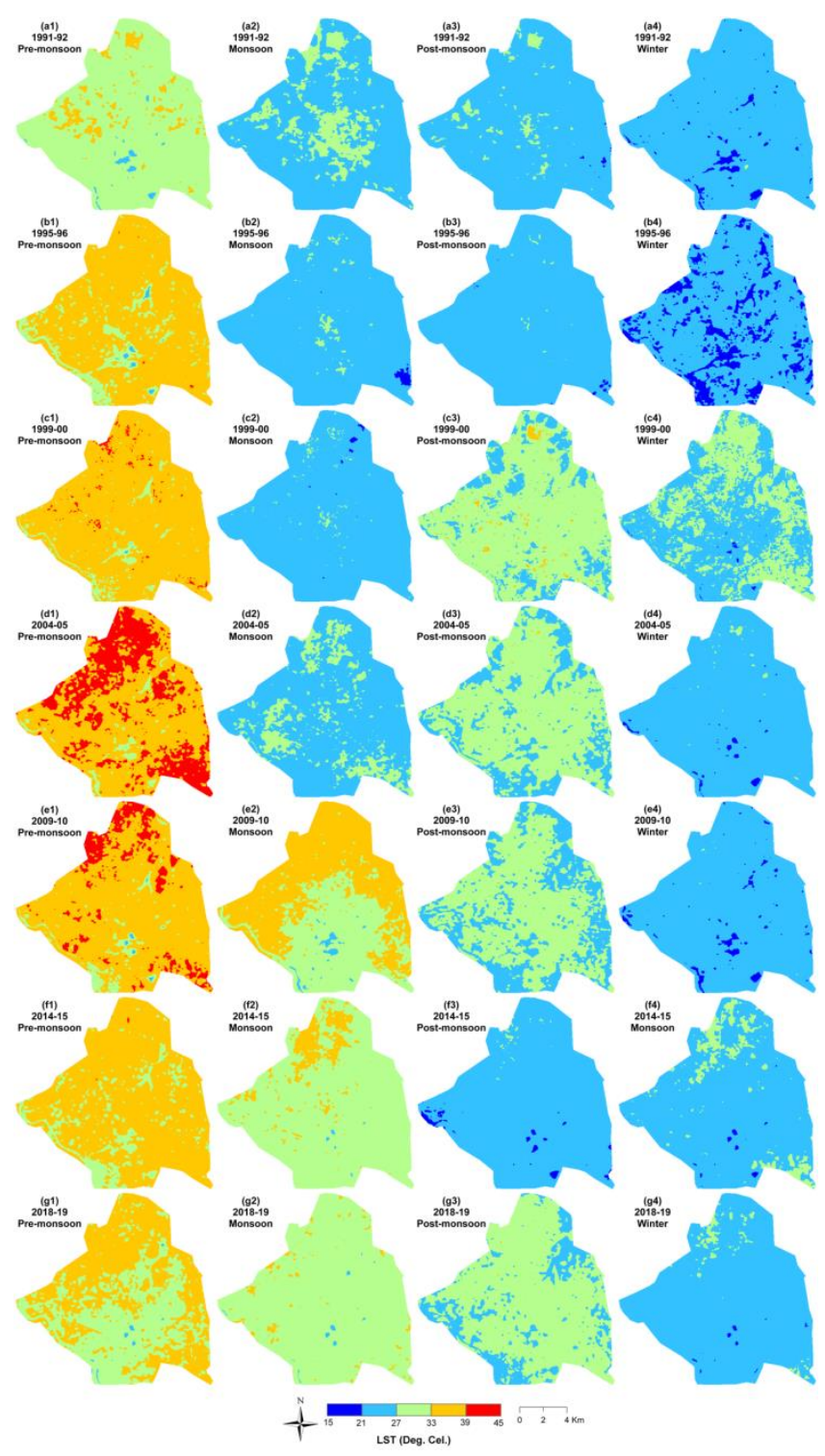

Figure 3. Seasonal distribution of LST: (a1,a2,a3a4) 1991-1992; (b1,b2,b3,b4) 1995-1996; (c1,c2,c3,c4) 1999-2000; (d1,d2,d3,d4) 2004-2005; (e1,e2,e3,e4) 2009-2010; (f1,f2,f3,f4) 2014-2015; (g1,g2,g3,g4) 20182019.

Figure 4 shows the seasonal change in the spatial distribution of NDBaI from 1991-92 to 2018-19. The high and low NDBaI regions were seasonally stable since the 1991-92 sessions. The change was observed 
only in the values of the NDBaI, not in the distributional pattern. The central part and the periphery of the city show the reverse value of the NDBaI.

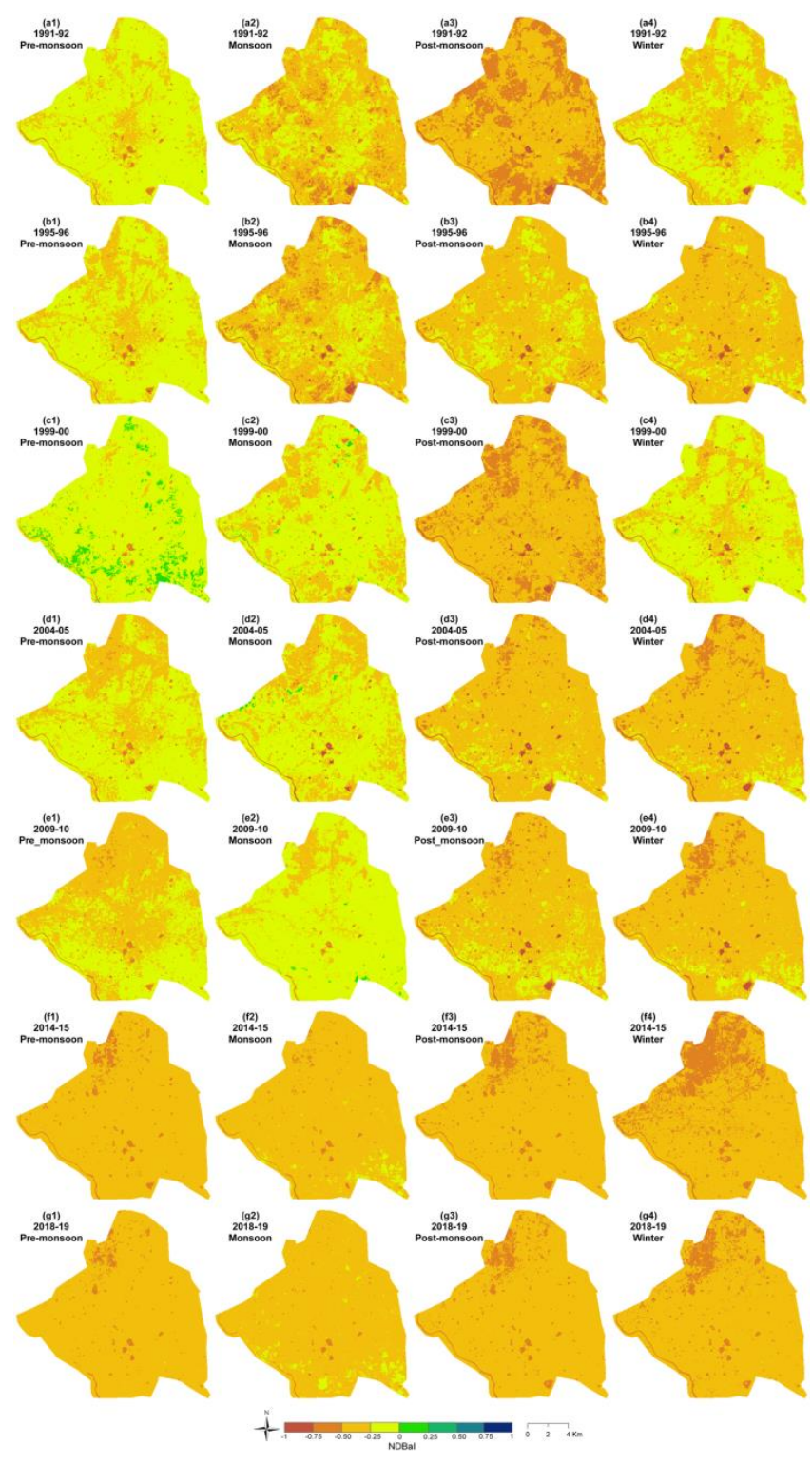

Figure 4. Seasonal distribution of NDBaI: (a1,a2,a3,a4) 1991-1992; (b1,b2,b3,b4) 1995-1996; (c1,c2,c3,c4) 1999-2000;(d1,d2,d3,d4) 2004-2005; (e1,e2,e3,e4) 2009-2010; (f1,f2,f3,f4) 2014-2015; (g1,g2,g3,g4) 20182019.

\subsection{Seasonal Variation on LST-NDBaI Relationship}

Figure 5 (a-d) shows the seasonal variation of LSTNDBaI relationships on different categories of LULC. This relationship is strongly positive on water bodies and wetland, strong to moderate positive on vegetation covered area, and moderate positive on the bare land/built-up area. The pre-monsoon season (Figure $5(\mathrm{a})$ ) has a strong positive LST-NDBaI correlation on the water bodies (0.65) and a moderate positive correlation on green vegetation (0.37), bare land, and built-up area (0.35). In the monsoon season, the correlation is strongly positive on green vegetation $(0.56)$ and water bodies (0.51), whereas it is moderate positive $(0.43)$ on bare land and built-up area (Figure $5(\mathrm{~b})$ ). In the post- monsoon season,the best correlation has been built on green vegetation (0.62), followed by the water bodies (0.53), bare land and built-up area (0.48) (Figure 5(c)). In winter (Figure 5(d)), the LST-NDBaI correlation is strongly positive on water bodies (0.62) and green vegetation (0.54), whereasit is moderate positive $(0.39)$ on the bare lands and built-up areas.

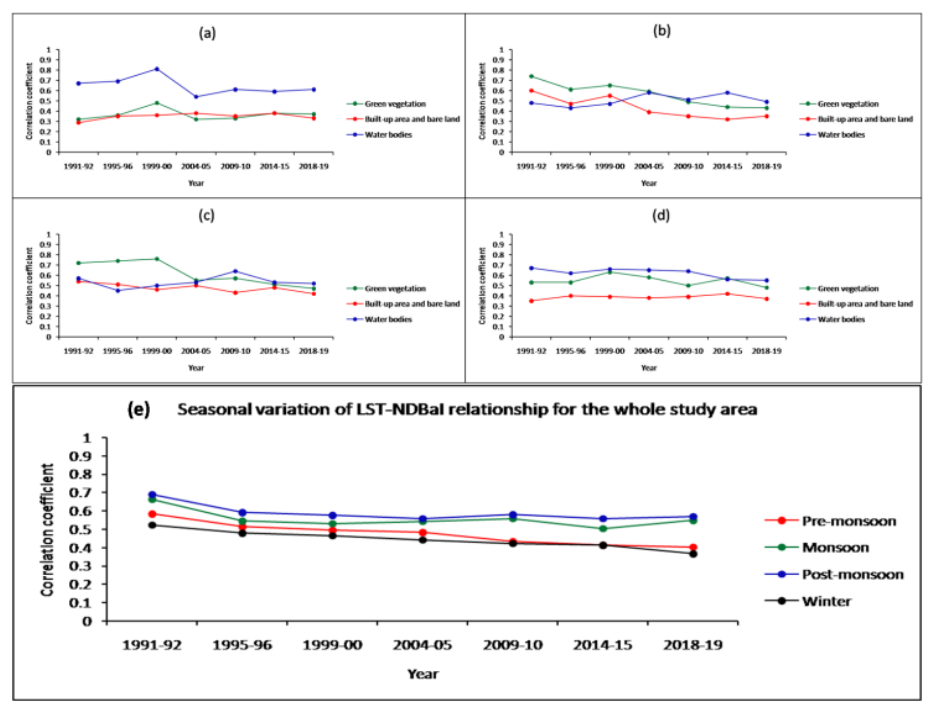

Figure 5. (a-d) Seasonal variation of the LST-NDBaI relationship on various categories of LULC: (a) Premonsoon; (b) Monsoon; (c) Post-monsoon; (d) Winter; (e) Seasonal variation of the LST-NDBaI relationship for the whole of the study area ( 0.05 level of significance).

Figure 5(e) represents the seasonal variation of LSTNDBaI relationships for the whole of the study area. The relationship is positive, for each season. The postmonsoon season presents the best correlation. The results also shows that the dry climate decreases the strength of the regression, while the moist climate increases the strength.

The study shows that LST builds a stable and strong to moderate positive correlation with NDBaI in Raipur City, India throughout the period. The result is comparable to the recently conducted other similar studies on the different urban agglomerations in the world. Essa et al. (2012) have shown that NDBaI generates a positive correlation (0.39) with LST in the Greater Dublin region, Ireland. A study conducted in Kunming of China shows that NDBaI and LST generate strong positive correlation (Chen and Zhang 2017). A weak positive correlation between LST and NDBaI has been presented in London (0.086) and Baghdad (0.469) by Ali et al. (2017). This relationship was also positive (0.458) in Kolkata Metropolitan Area, India (Nimish et al. 2020). The LST and NDBaI have built a weak negative correlation (-0.11) in Guangzhou, China (Guo et al. 2015). This correlation was weak positive (0.06) in Harare Metropolitan City, Zimbabwe (Mushore et al. 2017). Sharma and Joshi (2016) have shown the moderate positive nature of LSI-NDBaI correlation in the National Capital Region of India. The present study shows that the average correlation coefficient between LST and NDBaI of all the four seasons from 1991-92 to 2018-19 is moderate positive $(0.052)$, which can be 
considered as a very stable and authentic relationship between the two variables.

The present study is useful for the urban and environmental planning. The bare or fallow lands can be converted into road vegetation, park, wetland, or water bodies to resist the increasing rate of LST, at least to some extent.

\section{CONCLUSION}

The present study deals with the seasonal estimation of the relation between NDBaI and LST in Raipur City. It is seen that LST is directly correlated to NDBaI for all the seasons. This relationship varies in accordance with the variation of LULC. This correlation remains strong on the water bodies, irrespective of any season. On green vegetation, this correlation is moderate in premonsoon season and strong in the other three seasons. The barren land and settlement produce a moderate correlation for all the four seasons. Among the four seasons, the post-monsoon season builds the best LSTNDBaI correlation for all LULC types, whereas the premonsoon season has the least correlation. Among the various LULC categories, the water bodies present the best positive LST-NDBaI correlation, irrespective to any season. The high ratio of green plants and water surface can enhance the ecological health. Thus, this research work can be beneficial for the environmental planners. It is also suitable for the land use scientist and geographers. The study can be further expanded by the remote sensing scientist by apply the same methods on other satellite sensors and for different physical environment.

\section{ACKNOWLEDGEMENT}

The author is indebted to the United States Geological Survey (URL-3).

\section{Author contributions}

Subhanil Guha: Conceptualization, Methodology, Writing-Original draft preparation, Data curation, Validation, Software. Himanshu Govil: Visualization, Investigation, Writing-Reviewing and Editing.

\section{Conflicts of interest}

The authors declare no conflicts of interest.

\section{REFERENCES}

Ahmed B, Kamruzzaman M, Zhu X, Rahman M S \& Choi K (2013). Simulating Land Cover Changes and Their Impacts on Land Surface Temperature in Dhaka, Bangladesh. Remote Sensing, 5(11), 5969-5998. https://doi.org/10.3390/rs5115969

Alexander C (2020). Normalised difference spectral indices and urban land cover as indicators of land surface temperature (LST). International Journal of Applied Earth Observation and Geoinformation, 86, 102013. https://doi.org/10.1016/j.jag.2019.102013

Alibakhshi Z, Ahmadi M\& Farajzadeh Asl M (2020). Modeling Biophysical Variables and Land Surface
Temperature Using the GWR Model: Case StudyTehran and Its Satellite Cities. Journal of Indian Society of Remote Sensing,48, 59-70. https://doi.org/10.1007/s12524-019-01062-x

Ali J M, Marsh S H\& Smith M J (2017). A comparison between London and Baghdad surface urban heat islands and possible engineering mitigation solutions. Sustainable Cities and Society, 29, 159168. https://doi.org/10.1016/j.scs.2016.12.010

As-syakur A R, Adnyana I W S, Arthana I W \& Nuarsa I W (2012). Enhanced Built-Up and Bareness Index (EBBI) for Mapping Built-Up and Bare Land in an Urban Area. Remote Sensing, 4(10), 2957-2970. https://doi.org/10.3390/rs4102957

Barsi J, Schott J, Hook S, Raqueno N, Markham B\& Radocinski R (2014). Landsat-8 thermal infrared sensor (TIRS) vicarious radiometric calibration. Remote Sensing, 6(11), 11607-11626.

Carlson T N\& Ripley D A (1997). On the Relation between NDVI, Fractional Vegetation Cover, and Leaf Area Index. Remote Sensing of Environment, 62, 241-252. https://doi.org/10.1016/S00344257(97)00104-1

Chen X L, Zhao H M, Li P X\& Yi Z Y (2006). Remote sensing image-based analysis of the relationship between urban heat island and land use/cover changes. Remote Sensing of Environment, 104(2), 133-146. https://doi.org/10.1016/j.rse.2005.11.016

Chen X\& Zhang Y (2017). Impacts of urban surface characteristics on spatiotemporal pattern of land surface temperature in Kunming of China. Sustainable Cities and Society, 32, 87-99. https://doi.org/10.1016/j.scs.2017.03.013

Essa W, Verbeiren B, Van der Kwast J, Van de Voorde T\& Batelaan 0 (2012). Evaluation of the DisTrad thermal sharpening methodology for urban areas. International Journal of Applied Earth Observation and Geoinformation, 19, 163-172. https://doi.org/10.1016/j.jag.2012.05.010

Guha S, Govil H, Dey A \& Gill N (2020a). A case study on the relationship between land surface temperature and land surface indices in Raipur City, India. Geografisk Tidsskrift-Danish Journal of Geography, $120(1)$

35-50. https://doi.org/10.1080/00167223.2020.1752272

Guha S, Govil H, Gill N \& Dey A (2020b). Analytical study on the relationship between land surface temperature and land use/land cover indices. Annals of GIS, 26(2), 201-216.

https://doi.org/10.1080/19475683.2020.1754291

Guha S, Govil H \& Mukherjee S (2017). Dynamic analysis and ecological evaluation of urban heat islands in Raipur city, India. Journal of Applied Remote Sensing, 11(3), 036020. https://doi:10.1117/1.JRS.11.036020

Guo G, Wu Z\& Chen Y (2014). Estimation of subpixel land surface temperature using Landsat TM imagery: A case examination over a heterogeneous urban area. Third International Workshop on Earth Observation and Remote Sensing Applications (EORSA), Changsha, p. 304-308. https://doi.org/10.1109/EORSA.2014.6927900 
Guo G, Wu Z, Xiao R, Chen Y, Liu X\& Zhang X (2015). Impacts of urban biophysical composition on land surface temperature in urban heat island clusters. Landscape and Urban Planning, 135, 1-10. https://doi.org/10.1016/j.landurbplan.2014.11.007

Hao X, Li W\& Deng H (2016). The oasis effect and summer temperature rise in arid regions-case study in Tarim Basin. Scientific Reports, 6, 35418. https://doi.org/10.1038/srep35418

Jain S, Sannigrahi S, Sen S, Bhatt S, Chakraborti S\& Rahmat S (2020). Urban heat island intensity and its mitigation strategies in the fast-growing urban area. Journal of Urban Management, 9(1), 54-66. https://doi.org/10.1016/j.jum.2019.09.004

Li J (2006). Estimating land surface temperature from Landsat-5 TM. Remote Sensing Technology and Application, 21, 322-326.

Li Z N, Duan S B, Tang B H, Wu H, Ren H G\& Yan G J (2016). Review of methods for land surface temperature derived from thermal infrared remotely sensed data. Journal of Remote Sensing, 20, 899-920.

Macarof P, Bîrlica I C\& Stătescu F (2017). Investigating the relationship between land surface temperature and urban indices using landsat-8: a case study of Iași. Lucrările Seminarului Geografic Dimitrie Cantemir, 45, 81-88. https://doi.org/10.15551/lsgdc.v45i0.07

Mushore T D, Odindi J, Dube T\& Mutanga O (2017). Prediction of future urban surface temperatures using medium resolution satellite data in Harare metropolitan city, Zimbabwe. Building and Environment, 122, 397-410. https://doi.org/10.1016/j.buildenv.2017.06.033

Nimish G, Bharath H A\& Lalitha A (2020). Exploring temperature indices by deriving relationship between land surface temperature and urban landscape. Remote Sensing Application: Society and Environment, 18, 100299. https://doi.org/10.1016/j.rsase.2020.100299

Qin Z, Karnieli A\& Barliner P (2001). A Mono-Window Algorithm for Retrieving Land Surface Temperature from Landsat TM Data and Its Application to the Israel-Egypt Border Region. International Journal of Remote Sensing, 22(18), 3719-3746. https://doi:10.1080/01431160010006971

Sekertekin A, Kutoglu SH \& Kaya S (2016). Evaluation of spatio-temporal variability in Land Surface Temperature: A case study of Zonguldak, Turkey. Environmental Monitoring and Assessment, 188, 30. https://doi.org/10.1007/s10661-015-5032-2

Sharma R, Ghosh A\& Joshi P K (2013). Mapping environmental impacts of rapid urbanization in the National Capital Region of India using remote sensing inputs. Geocarto International, 28(5), 420-
438.

https://doi.org/10.1080/10106049.2012.715208

Sharma R\& Joshi P K (2016). Mapping environmental impacts of rapid urbanization in the National Capital Region of India using remote sensing inputs. Urban Climate, 15, 70-82. https://doi.org/10.1016/j.uclim.2016.01.004

Sobrino J A, Raissouni N\& Li Z (2001). A comparative study of land surface emissivity retrieval from NOAA data. Remote Sensing of Environment,75(2), 256266. https://doi.org/10.1016/S00344257(00)00171-1

Sobrino J A, Jimenez-Munoz J C \& Paolini L (2004). Land surface temperature retrieval from Landsat TM5.Remote Sensing of Environment, 9, 434-440. https://doi:10.1016/j.rse.2004.02.003

Sun Q, Tan J \& Xu Y (2010). An ERDAS image processing method for retrieving LST and describing urban heat evolution: A case study in the Pearl River Delta Region in South China. Environmental Earth Science, 59, 1047-1055.

Tomlinson C J, Chapman L, Trones J E\& Baker C (2011). Remote sensing land surface temperature for meteorology and climatology: a review. Meteorological Application, 118, 296-306. https://doi.org/10.1002/met.287

URL-1: hthttp://www.surveyofindia.gov.in

URL-2: http://www.raipur.gov.in

URL-3: https://www.earthexplorer.usgs.gov

URL-4: http://www.imdraipur.gov.in

Vlassova L, Perez-Cabello F, Nieto H, Martín P, Riaño D, \& De La Riva J (2014). Assessment of methods for land surface temperature retrieval from Landsat-5 TM images applicable to multiscale tree-grass ecosystem modeling. Remote Sensing, 6(5), 4345-4368.

Wukelic G E, Gibbons D E, Martucci L M\&Foote H P (1989). Radiometric calibration of Landsat Thematic Mapper thermal band. Remote Sensing of Environment, 28, 339-347. https://doi.org/10.1016/0034-4257(89)90125-9

Yang J\& Que J (1996). The empirical expressions of the relation between precipitable water and ground water vapor pressure for some areas in China.Scientia Atmospherica Sinica, 20, 620-626.

Zanter K (2019). Landsat 8 (L8) Data Users Handbook; EROS: Sioux Falls, SD, USA.

Zhao H M \& Chen X L (2005). Use of normalized difference bareness index in quickly mapping bare areas from TM/ETM+. Geoscience and Remote Sensing Symposium. 3 (25-29), p.1666-1668. https://doi.org/10.1109/IGARSS.2005.1526319 